University of New Hampshire

University of New Hampshire Scholars' Repository

Earth Systems Research Center

Institute for the Study of Earth, Oceans, and

Space (EOS)

10-1-1996

\title{
Analyzing the discharge regime of a large tropical river through remote sensing, ground-based climatic data, and modeling
}

Charles J. Vorosmarty

University of New Hampshire, Durham, charles.vorosmarty@unh.edu

Cort J. Willmott

Bhaskar J. Choudhury

Annette L. Schloss

University of New Hampshire, Durham, Annette.Schloss@unh.edu

Timothy K. Stearns

See next page for additional authors

Follow this and additional works at: https://scholars.unh.edu/ersc

Comments

This is an article published by AGU in Water Resources Research in 1996, available online: https://dx.doi.org/10.1029/

96WR01333

\section{Recommended Citation}

Vorosmarty, C.J., C.J. Willmott, B.J. Choudhury, A.L. Schloss, T.K. Stearns, S.M. Robeson, and T.J. Dorman. (1996) Analyzing the discharge regime of a large tropical river through remote sensing, groundbased climatic data, and modeling. Water Resources Research, 32: 3137-50. https://dx.doi.org/10.1029/ 96WR01333

This Article is brought to you for free and open access by the Institute for the Study of Earth, Oceans, and Space (EOS) at University of New Hampshire Scholars' Repository. It has been accepted for inclusion in Earth Systems Research Center by an authorized administrator of University of New Hampshire Scholars' Repository. For more information, please contact Scholarly.Communication@unh.edu. 


\section{Authors}

Charles J. Vorosmarty, Cort J. Willmott, Bhaskar J. Choudhury, Annette L. Schloss, Timothy K. Stearns, Scott M. Robeson, and Timothy J. Dorman 


\title{
Analyzing the discharge regime of a large tropical river through remote sensing, ground-based climatic data, and modeling
}

\author{
Charles J. Vörösmarty, ${ }^{1}$ Cort J. Willmott, ${ }^{2}$ Bhaskar J. Choudhury, ${ }^{3}$ \\ Annette L. Schloss, ${ }^{1}$ Timothy K. Stearns, ${ }^{1}$ Scott M. Robeson, ${ }^{4}$ \\ and Timothy J. Dorman ${ }^{5}$
}

\begin{abstract}
This study demonstrates the potential for applying passive microwave satellite sensor data to infer the discharge dynamics of large river systems using the main stem Amazon as a test case. The methodology combines (1) interpolated ground-based meteorological station data, (2) horizontally and vertically polarized temperature differences (HVPTD) from the 37-GHz scanning multichannel microwave radiometer (SMMR) aboard the Nimbus 7 satellite, and (3) a calibrated water balance/water transport model (WBM/WTM). Monthly HVPTD values at $0.25^{\circ}$ (latitude by longitude) resolution were resampled spatially and temporally to produce an enhanced HVPTD time series at $0.5^{\circ}$ resolution for the period May 1979 through February 1985. Enhanced HVPTD values were regressed against monthly discharge derived from the WBM/WTM for each of 40 grid cells along the main stem over a calibration period from May 1979 to February 1983 to provide a spatially contiguous estimate of time-varying discharge. HVPTD-estimated flows generated for a validation period from March 1983 to February 1985 were found to be in good agreement with both observed and modeled discharges over a $1400-\mathrm{km}$ section of the main stem Amazon. This span of river is bounded downstream by a region of tidal influence and upstream by low sensor response associated with dense forest canopy. Both the WBM/WTM and HVPTD-derived flow rates reflect the significant impact of the 19821983 El Niño-Southern Oscillation (ENSO) event on water balances within the drainage basin.
\end{abstract}

\section{Introduction}

The water cycle is an important component of the Earth system, and numerous uncertainties remain about pool sizes, their dynamics, and their changes due to human activities [Committee on Global Change, 1988; World Climate Research Programme, 1992; Chahine; 1992; Watson et al., 1996]. Particular attention has been paid toward refining our representation of the dynamics of evapotranspiration [Wood, 1991; Henderson-Sellers and Brown, 1992; Kalma and Calder, 1994], soil moisture [Mintz and Serafini, 1984, 1989; Willmott et al., 1985a; Serafini and Sud, 1987; Mintz and Walker, 1993; Webb and Rosenzweig, 1993], and precipitation [Legates and Willmott, 1990b; Arkin and Janowiak, 1991; Global Precipitation Climatology Centre (GPCC), 1992; Simpson, 1992]. Much less attention has been paid to the dynamics of river systems, although river discharge can provide validation for both empirical water balance models and climate simulations. River heights and

\footnotetext{
${ }^{1}$ Institute for the Study of Earth, Oceans and Space, University of New Hampshire, Durham.

${ }^{2}$ Center for Climatic Research, Department of Geography, University of Delaware, Newark.

${ }^{3}$ Hydrological Sciences Branch, NASA Goddard Space Flight Center, Greenbelt, Maryland.

${ }^{4}$ Department of Geography, Indiana University, Bloomington.

${ }^{5}$ Science Systems and Applications, Inc., Lanham, Maryland.

Copyright 1996 by the American Geophysical Union.

Paper number 96WR01333.

0043-1397/96/96WR-01333\$09.00
}

flows are also of importance to a myriad of landscape processes including the generation and transport of sediment, nutrients, and carbon; the ecology of lotic and wetland ecosystems; and through floodplain inundation the consequent generation of radiatively important gases.

Global inventories of river discharge are available [Global Runoff Data Centre, 1993; United Nations Educational, Scientific, and Cultural Organization (UNESCO), Discharge of Selected Rivers of the World, various years], and have been exercised recently in studies of the water cycle over broad spatial domains [Amell and Reynard, 1989; Mintz and Serafini, 1989; Vörösmarty et al., 1989, 1991; Dümenil and Todini, 1992]. The decline in hydrometeorological monitoring stations [World Meteorological Organization/United Nations Educational, Scientific, and Cultural Organization (WMO/UNESCO), 1991; Rodda et al., 1993] over the last decades has important implications for our understanding of the hydrologic cycle. The loss is particularly acute in the tropics, where demands for water resources and hence reliable engineering information have been rising dramatically.

Remote sensing of inland waters is a potentially important source of information in light of such losses in ground-based monitoring capacity. Recent work using Geosat altimetry [Koblinsky et al., 1993; Morris and Gill, 1994; Birkett, 1994] to measure river and lake levels have shown promise. Imhoff et al. [1987] used L band synthetic aperture radar (SIR-B) in conjunction with Landsat Multispectral Scanner (MSS) and ground-based stage data to determine flood boundaries along the lower Ganges River. 
Giddings and Choudhury [1989] demonstrated that passive microwave sensors also could be used in this context. The scanning multichannel microwave radiometer (SMMR) launched aboard the Nimbus 7 satellite collected coincident observations of horizontally and vertically polarized brightness temperature ( $T_{h}$ and $T_{v}$, respectively) at $37 \mathrm{GHz}$ from November 1978 through August 1987 at a spatial resolution of about $25 \mathrm{~km}$. Inspection of these observations, together with radiative transfer analysis, show that in the tropics, the spatial and temporal variations of the $37-\mathrm{GHz}$ polarization temperature difference $\left(\Delta T=T_{v}-T_{h}\right)$ are determined primarily by the structure and phenology of vegetation and seasonal inundation of major rivers and wetlands. Seasonal variation of atmospheric precipitable water has a modulating effect on the seasonal variation of $\Delta T$ [Choudhury et al., 1992]. In the context of the current study these horizontally and vertically polarized temperature differences (HVPTD) have been shown to be positively correlated with variations in water level for many large South American rivers and wetland systems [Giddings and Choudhury, 1989]. Since the SMMR is global in coverage and maintains a 6-day return period, it offers an opportunity for monitoring the changing hydrologic status of such systems over broad geographic domains.

Choudhury [1989] reviewed numerous theoretical aspects associated with the $37-\mathrm{GHz}$ data obtained from the Nimbus 7 SMMR. Polarization temperature differences at this frequency are related to the dipolar moment of water and the sensor should yield an HVPTD value of $60^{\circ} \mathrm{K}$ for pixels composed entirely of open water, $4^{\circ} \mathrm{K}$ for closed canopy, and intermediate values for vegetated floodplains. For the $25-\mathrm{km}$ pixel of the SMMR, mixtures of open water, uplands, and floodplains will be common, and each sensor reading will be a composite of HVPTD values determined by the distribution of these contrasting landscapes. In regions dominated by periodically inundated floodplains, HVPTD values show the greatest temporal variation since flooding reduces the proportional contribution of upland landscapes to the overall HVPTD signal, while recession has the opposite effect. This concept was tested by Sippel et al. [1994] in a 35,000- $\mathrm{km}^{2}$ area located on the main stem Amazon to determine the area of fractional floodplain inundation. They determined that inundated floodplain was associated with an HVPTD of $17.4^{\circ} \mathrm{K}$ and used time variations in the composite HVPTD signal, together with linear mixing models of the end-member microwave signatures, to construct a time series of flooding over this domain.

In large floodplain-dominated rivers, variations in water heights therefore impart a hydrological signal detectable through the use of 37-GHz SMMR imagery. Since variations in stage are related to variations in discharge, there is also a potential for monitoring river flows remotely. In the Amazon, stage-discharge relationships (i.e., rating curves) are a standard hydrometric technique used routinely by the Brazilian Departmento Nacional de Aguas Energia Electrica to compute flows along the main stem Amazon and its tributaries [Richey et al., 1989]. We will exploit the connection between stage, seasonal inundation, and discharge and relate these to time series of 37-GHz SMMR HVPTD. The purpose of this study is to demonstrate the potential for applying 37-GHz passive microwave data to generate remotely sensed, contiguous discharge hydrographs along the main stem Amazon River and to test the limits of the approach. It prepares a framework for monitoring other large rivers and for exploring the use of contemporary and future passive microwave data sets in conjunction with hydrological models.

\section{Methods \\ Study Area}

The setting for this analysis is the Amazon River drainage basin (Figure 1), a river system that encompasses 5.8 million $\mathrm{km}^{2}$ [van der Leeden et al., 1990]. The basin is complex from a hydrological standpoint. It includes upland mountainous reaches, granitic shield areas, and an extensive lowland floodplain system. Although it still maintains the world's largest stand of natural tropical evergreen forest, it drains a variety of other natural forested and nonforested ecosystems (see Table 1) and lands subject to human disturbance [Skole and Tucker, 1993]. Water recycling is prevalent [Salati and Vose, 1984], and its disruption by land use change poses grave concerns about regional and global climate [Dickinson and Henderson-Sellers, 1988; Lean and Warrilow, 1989; Shukla et al., 1990].

In this study we consider the main stem Amazon River to begin in the Brazilian state of Amazonas (about $71.5^{\circ} \mathrm{W}, 4.0^{\circ} \mathrm{S}$ ), progress downstream through the large floodplain-dominated channel system, and end at a point close to the city of Óbidos (about $56.0^{\circ} \mathrm{W}, 2.0^{\circ} \mathrm{S}$ ). We limited our analysis to this portion of the river to avoid complications associated with coastal tides. Floodplain extent within Brazil has been estimated at $92,400 \mathrm{~km}^{2}$ along the main stem with an additional $62,000 \mathrm{~km}^{2}$ along the major tributaries [Sippel et al., 1992]. Vörösmarty et al. [1989] and Richey et al. [1989] analyzed hydrographs along the main stem and found that floodplain inundation must be considered in any analysis of discharge within the main stem. The Amazon has a final entry to the sea located approximately $1000 \mathrm{~km}$ downstream of Óbidos, with discharges of over $200,000 \mathrm{~m}^{3} / \mathrm{s}$. This flow represents approximately $15 \%$ of the global delivery of fresh water to the oceans. Comprehensive descriptions of the hydrography of the river system can be found in work by Sioli [1984] and Rzóska [1978].

\section{Climatic Time Series}

Representative climatic time series of monthly precipitation $(P)$ and air temperature $(T)$ were estimated from station-data archives compiled by Legates and Willmott [1990a, b] and Vose et al. [1992] and a spatial interpolation methodology presented and evaluated by Willmott and Robeson [1995]. Willmott and Robeson's algorithm makes use of a climatological (long-term average) monthly $\bar{P}$ or $\bar{T}$ field to assist in interpolating any particular monthly $P$ or $T$ field of interest. It also relies on Willmott et al.'s [1985b] spherical implementation of Shepard's [1968] inverse-distance weighting procedure. All interpolations, whether to stations or a spherical grid, are made with the Willmott et al. [1985b] algorithm. Termed "climatologically aided interpolation" (CAI), Willmott and Robeson's procedure improves upon the simple interpolation from station observations by exploiting the spatial colinearity between $P$ and $\bar{P}$ (or between $T$ and $\bar{T}$ ) and the fact that observations of $\bar{P}$ and $\bar{T}$ are available at meaningfully higher spatial resolutions than are observations of $P$ and $T$. Using CAI, monthly fields of $P$ and $T$ were interpolated to a $0.5^{\circ}$ of latitude by $0.5^{\circ}$ of longitude resolution for each month within the period April 1979 through March 1985.

Illustrating CAI for monthly (January 1980) precipitation, long-term January means from Legates and Willmott's highresolution station climatology $(\bar{P})$ first are interpolated to all 
a)

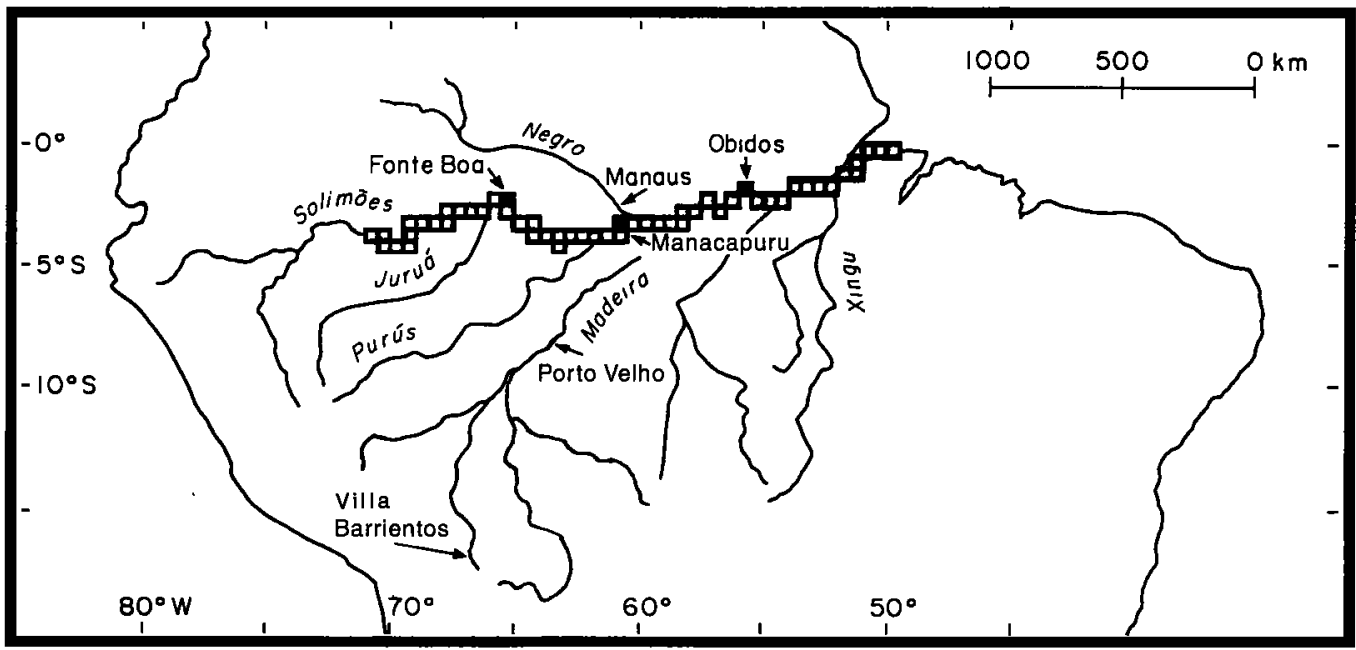

b)

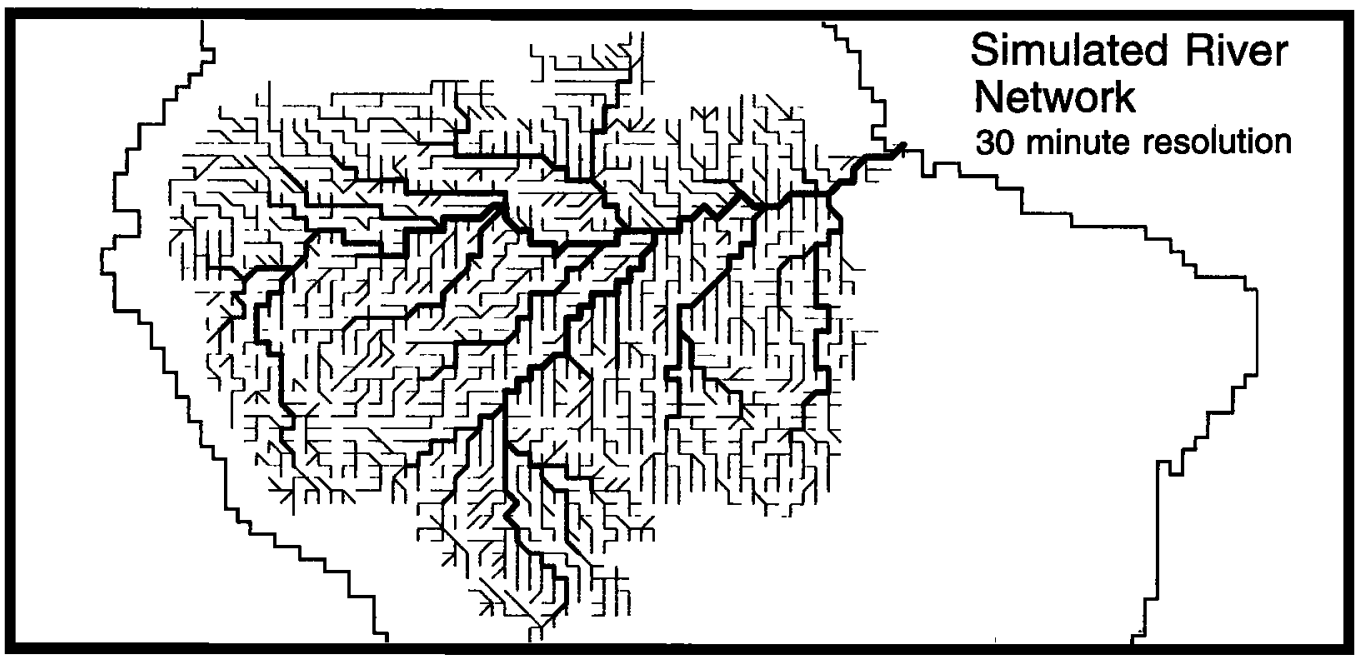

C)

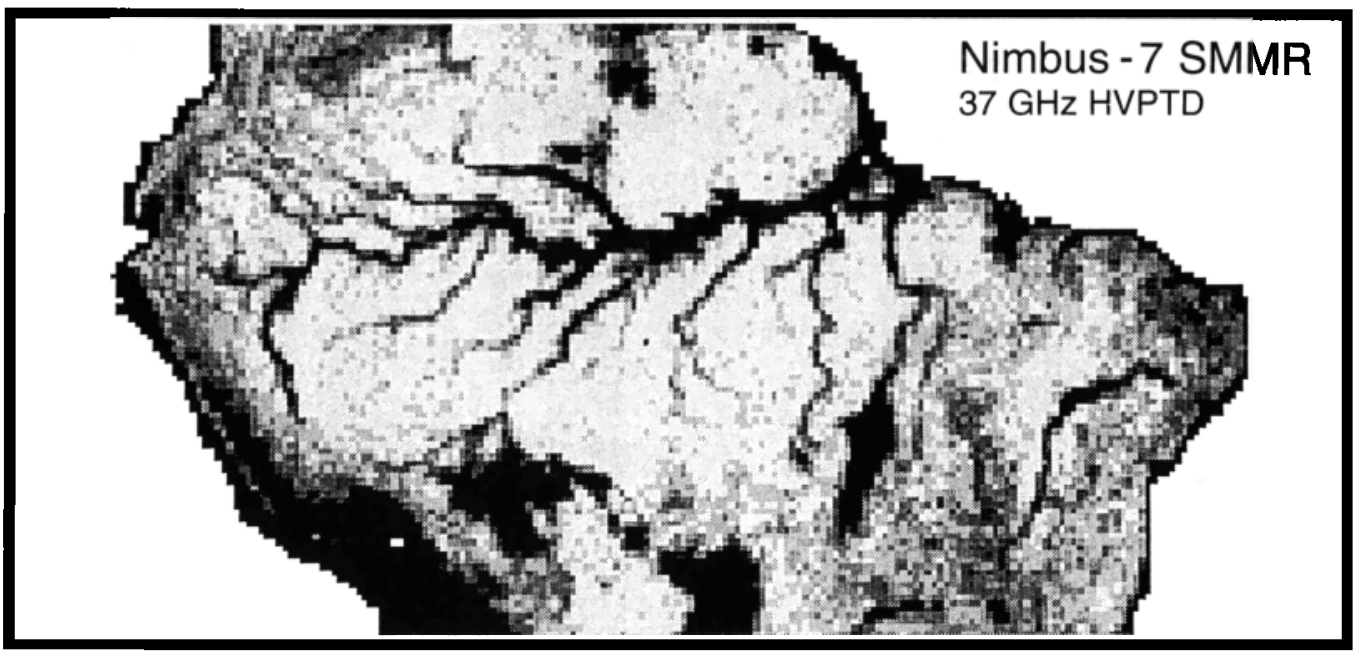

Figure 1. Study area considered in this analysis. (a) Pixels used to simulate the main stem Amazon River. (b) The overall simulated network topology used to route distributed runoff downstream. This river network was developed from Defense Mapping Agency Aerospace Center (DMAAC) [1980, 1981, 1982, 1983, 1984, 1986] maps. (c) An image of mean horizontally and vertically polarized temperature differences at $37 \mathrm{GHz}$ derived from the Nimbus 7 SMMR (mean for April). River corridors are clearly apparent in contrast to dense forest. Spatial resolution of Figures $1 \mathrm{a}$ and $1 \mathrm{~b}$ is $0.5^{\circ} \times 0.5^{\circ}$ (latitude by longitude) and of Figure $1 \mathrm{c}$ is $0.25^{\circ} \times 0.25^{\circ}$. 
Table 1. Available Water Capacities of Soils Used to Simulate Water Balances for the Amazon Drainage System

\begin{tabular}{|c|c|c|c|c|c|}
\hline \multirow[b]{2}{*}{ Vegetation Class } & \multicolumn{5}{|c|}{ Soil Texture Class } \\
\hline & Sand & Loam & Clay & $\begin{array}{l}\text { Clay } \\
\text { Loam }\end{array}$ & Lithosol \\
\hline Polar desert & & & $52(3)$ & & $13(17)$ \\
\hline Boreal woodland & & & & & $13(35)$ \\
\hline Temperate mixed forest & & & & & $13(9)$ \\
\hline Temperate deciduous forest & & & $152(1)$ & & $13(10)$ \\
\hline Tropical savanna & $195(6)$ & $195(16)$ & $87(49)$ & $130(47)$ & $13(3)$ \\
\hline Tropical evergreen forest & $325(36)$ & $260(524)$ & $152(797)$ & $208(75)$ & $13(46)$ \\
\hline Tropical deciduous forest & & $260(26)$ & $152(17)$ & $208(16)$ & 13 (11) \\
\hline Xeric woodland & $195(9)$ & $195(12)$ & & $130(2)$ & $13(12)$ \\
\hline Temperate evergreen forest & & & $152(33)$ & & $13(38)$ \\
\hline
\end{tabular}

Soils and vegetation classes were obtained from global archives [FAO/UNESCO, 1971; cf. Melillo et al. 1993]. Entries enclosed by parentheses are the number of grid cells represented by each combination.

Vose et al. [1992] stations $(j)$ for which January $1980 P_{j}$ are available. Among other variables, the Vose et al. [1992] station archive contains monthly time series of $P$ and $T$, and some of the station records extend back well into the nineteenth century. Each interpolated long-term mean $\left(\hat{\bar{P}}_{J}\right)$ then is subtracted from the January 1980 station precipitation value $\left(P_{J}\right)$ at the corresponding Vose et al. station $(j)$. A monthly (January 1980) precipitation deviation $\left(\delta P_{J}=P_{J}-\hat{\bar{P}}_{J}\right)$ is obtained in this fashion for each station. These station deviations $\left(\delta P_{j}\right)$ then are interpolated to a $0.5^{\circ} \times 0.5^{\circ}$ spherical grid. At each node of the grid $(i)$, the CAI estimate $\left(\hat{P}_{i}\right)$ is obtained by adding the interpolated deviation $\left(\delta \hat{P}_{i}\right)$ to an estimated Legates and Willmott $[1990 \mathrm{a}, \mathrm{b}]$ long-term average $\left(\hat{\bar{P}}_{i}\right)$, where each $\hat{\bar{P}}_{i}$ was previously interpolated from Legates and Willmott's 1,640 long-term station averages for South America. When $\delta \hat{P}_{i}$ is interpolated by Shepard's [1968] distance-related weighting, the CAI estimate can be written as

$$
\hat{P}_{\imath}=\delta \hat{P}_{\imath}+\hat{\bar{P}}_{\imath}
$$

where

$$
\delta \hat{P}_{l}=\sum_{j=1}^{n_{l}} w_{t \jmath}\left[\delta P_{\jmath}+\Delta\left(\delta P_{\jmath}\right)\right] / \sum_{\jmath=1}^{n_{l}} w_{i j}
$$

and $n_{i}$ is the number of nearby stations used to interpolate precipitation to grid node $i$, and $w_{i j}$ represents the influence that the precipitation deviation at station $j\left(\delta P_{j}\right)$ and its estimated spatial gradient $\left(\Delta\left(\delta P_{j}\right)\right)$ at $j$ have on the deviation estimate at grid node $i$. In addition to its inverse-distance weighting, Shepard's algorithm contains procedures for damping the deleterious influences of spatially clustered (autocorrelated) nearby stations and extrapolating beyond the range of $n$, nearby stations when the estimated spatial gradients at the nearby stations $\left(\Delta\left(\delta P_{j}\right)\right)$ warrant it. Mean absolute (interpolation) errors (MAEs), determined from cross validation at all of the stations, were on the order of $0.8^{\circ} \mathrm{C}$ for monthly temperature and about $40 \mathrm{~mm}$ for monthly precipitation, although the precipitation MAEs exhibit a strong seasonal oscillation that ranges from approximately 25 to $55 \mathrm{~mm}$.

Two biases contribute to the underestimation of areal precipitation averages made from the South American historical station record. Rain gauge undercatch contributes systematic errors on the order of 5\% [Legates and Willmott, 1990b]. Considerably larger errors, however, arise from the inability of the historical rain gauge networks to adequately resolve the spatial variability within precipitation [Willmott et al., 1994]. Illconditioned precipitation networks exist on most other continents; however, they tend to produce overestimates of largescale spatially averaged precipitation. Network-induced underestimation of large-scale areal averages in South America then is distinct [Willmott et al., 1994]. Reporting rain gauges in South America are sparse over most of the continent but especially so in the interior, where it is wet (e.g., within the Amazon Basin). It is this relative undersampling of the wetter regions that gives rise to the underestimation. Using typical network densities for South America, Willmott et al. [1994] illustrated that the network-induced underestimates in continental averages can be on the order of several hundred millimeters per year.

Our use of CAI reduces the magnitude of underestimation. In addition, for 11 sub-basins within the Amazon Basin, our gridded monthly precipitation estimates (obtained from CAI) were adjusted toward a balance with observed runoff and estimated evapotranspiration rates. Adjustment factors ranged between 0.90 and 1.45 . Within most of the 11 sub-basins, in other words, CAI-estimated monthly precipitation was adjusted in an upward direction. Our precipitation forcing of Amazon hydrology, in turn, is greater than that in most previous studies, but we believe it is relatively more accurate.

Substantial spatial and temporal variability are evident within the estimated $P$ and $T$ fields, especially within $P$ (Plate 1). Within South America the Amazon Basin maintains precipitation rates that are among the continent's highest. In addition, the basin is the major contributor to the total volume of precipitation delivered at the continental scale. Basin-wide yearly averages, made for each of the five complete water years (September through August) within the time frame of our study, exhibit single-year extrema of 2200 and $2450 \mathrm{~mm}$ (Table 2). Intra-annual variability also is quite large, primarily in response to the seasonal migration of the Intertropical Convergence Zone (ITCZ) over the basin (Plate 1). Temperature is less variable on virtually all spatial and temporal scales. Most of the Amazon basin is at or above $24^{\circ} \mathrm{C}$ throughout the year. Standard deviations of yearly average $T$ are about $0.6^{\circ} \mathrm{C}$, while corresponding monthly values are approximately $2.0^{\circ} \mathrm{C}$. It is worth noting that our analysis encompasses the $\mathrm{El} \mathrm{Niño-}$ Southern Oscillation (ENSO) event that began in late 1982. 

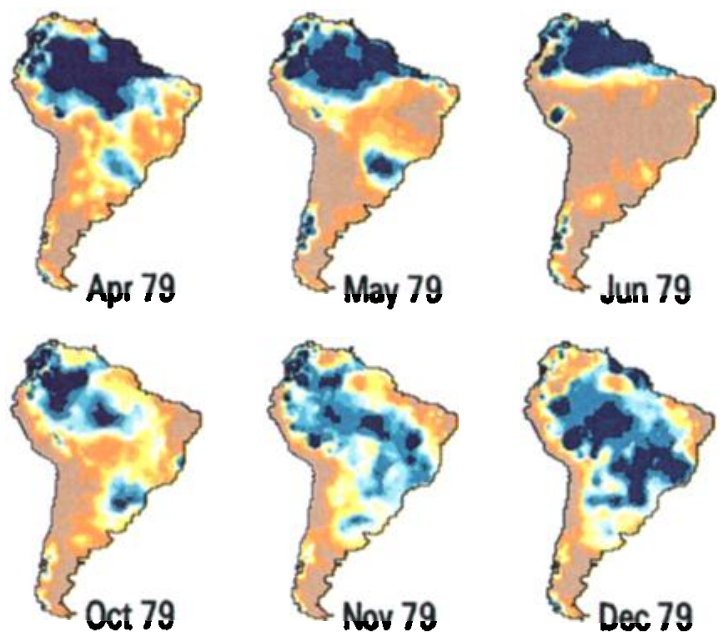

Oct 79
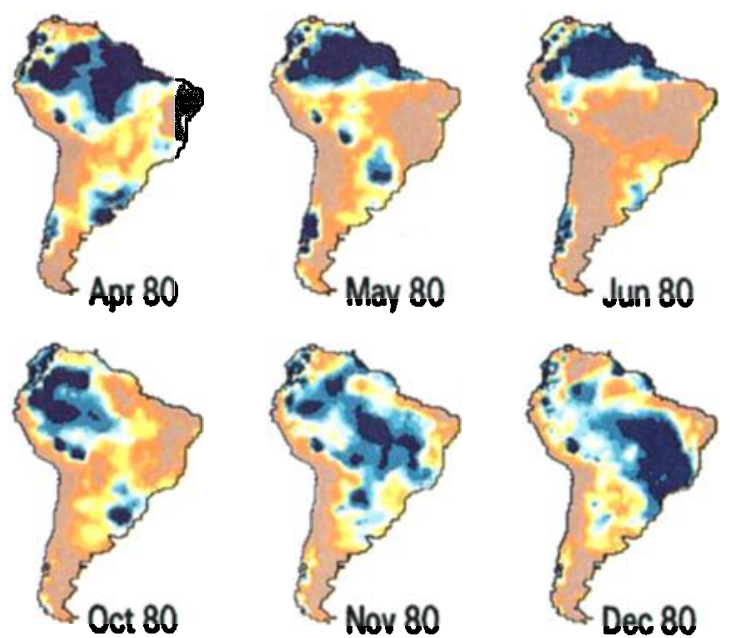
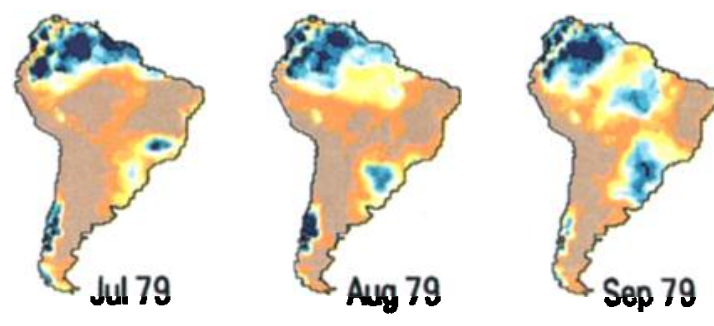

Precipitation
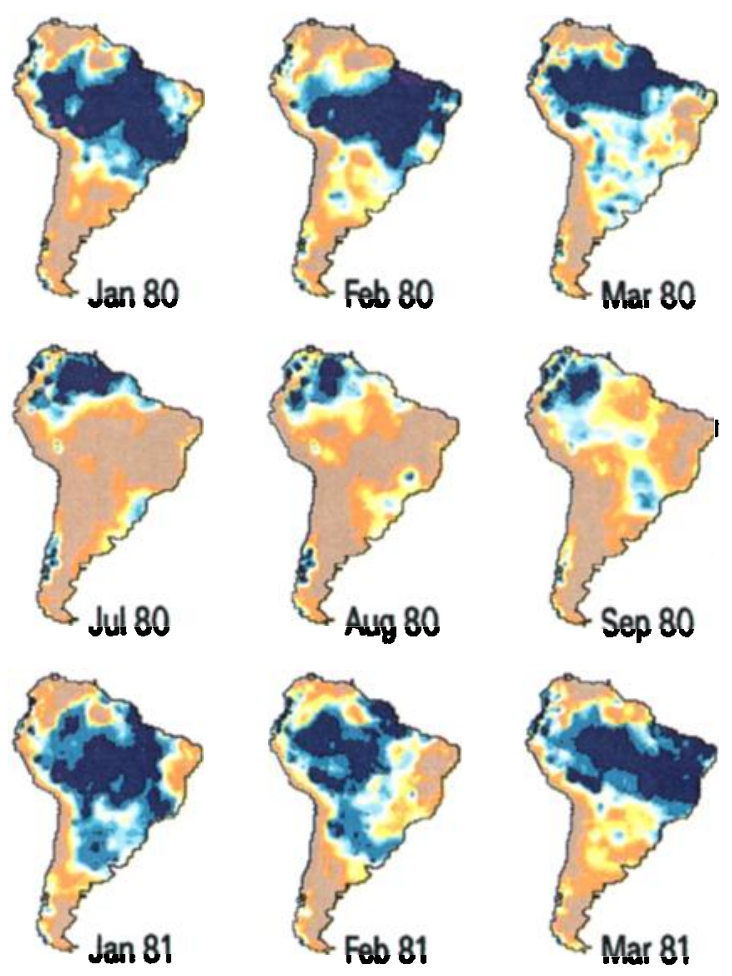

Plate 1. A portion of the 6-year time series for precipitation used in this study. These fields were developed using the climatologically aided interpolation (CAI) procedure described in the text. Simulated runoff and river discharge reflect the spatial and temporal variations embodied within such climatic forcings.

\section{Simulated Discharges}

The Water Balance/Water Transport Model (WBM/WTM) was used to generate a 6-year monthly time series of discharge for each $0.5^{\circ}$ cell representing the Amazon drainage basin. The model is described in the appendix to this paper and is based on work by Vörösmarty [1991], Vörösmarty and Moore [1991], and Vörösmarty et al. [1989, 1991]. The model relies on a series of biophysical data sets which specify land surface properties and climatic drivers depicting time-varying fields of precipitation and temperature. The combination of soils, vegetation, and available water capacities used here are given in Table 1. The WBM predicts monthly water balances, specifically soil moisture, evapotranspiration, and runoff on independent $0.5^{\circ}$ grid cells. This application of the WBM utilized a Thornth-

Table 2. Elements of the Computed Water Balance for the Amazon Basin, Upriver of Óbidos

\begin{tabular}{lccccc}
\hline & \multicolumn{5}{c}{ Water Year* } \\
\cline { 2 - 6 } & $1979-1980$ & $1980-1981$ & $1981-1982$ & $1982-1983$ & $1983-1984$ \\
\hline Precipitation & 2229 & 2306 & 2450 & 2200 & 2323 \\
Evapotranspiration & 1194 & 1210 & 1260 & 1263 & 1180 \\
Runoff & 1042 & 1091 & 1211 & 953 & 1131 \\
Discharge & 1030 & 1038 & 1222 & 975 & 1022 \\
$\Delta$ Basin storaget & +5 & +58 & -32 & -38 & +121 \\
$\Delta$ Soil moisture & 0 & +8 & -17 & -4 & +6 \\
\hline
\end{tabular}

All units are in millimeters per year.

* Each water year begins in September.

†Represents aggregate change in the following pools: soil moisture, runoff detention, channels, and floodplains. Water extraction by deeply rooted vegetation is not included in these calculations. 


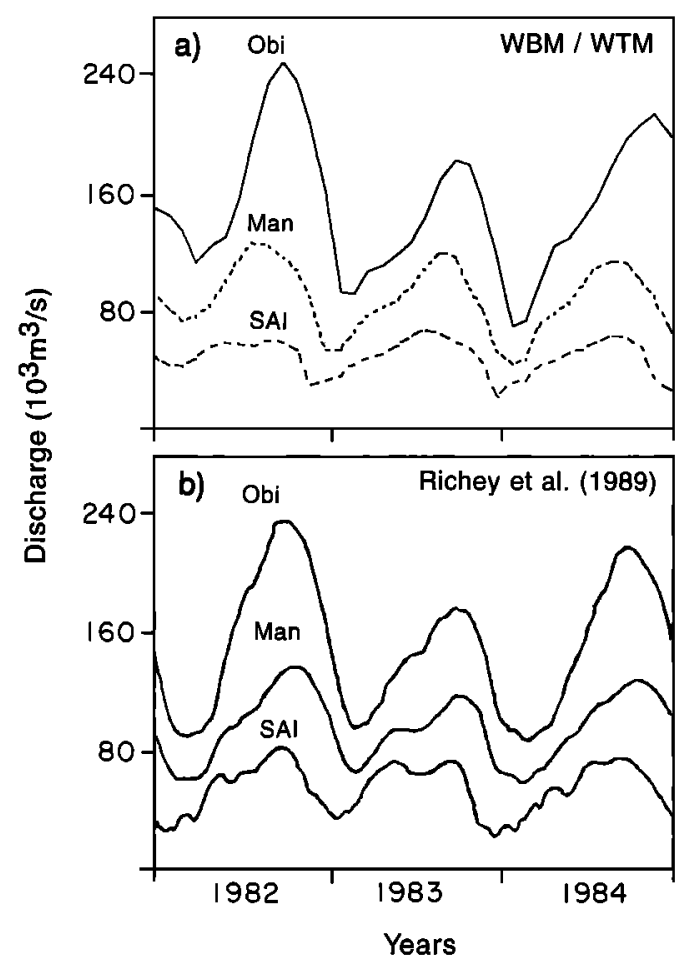

Figure 2. River discharge at three locations along the mainstem Amazon: (a) simulated in this study and (b) observed records from Richey et al. [1989]. The 1982-1983 ENSO event is evident in both time series as a significant decrease in discharge. Years given refer to water years starting in September (Obi, Óbidos, $56.0^{\circ} \mathrm{W}, 2.0^{\circ} \mathrm{S}$; Man, Manacapuru, $61.0^{\circ} \mathrm{W}, 3.5^{\circ} \mathrm{S}$; SAI, San Antonio do Ica, $67.5^{\circ} \mathrm{W}, 3.0^{\circ} \mathrm{S}$ ).

waite and Mather potential evapotranspiration (PET) function (as applied by Mintz and Walker [1993], Mintz and Serafini [1989], and Willmott et al. [1985a]) in conjunction with a statistical scaling function that accounts for submonthly soil moisture dynamics. The model yielded mean PET values for the entire basin $(1349 \mathrm{~mm} / \mathrm{yr})$ that were close to those determined from digitized versions of maps given by Korzoun et al. [1977] (1327 mm/yr).

The WTM routes runoff using a simulated network topology (Figure 1b) and a system of coupled differential equations. The WTM is a quasi-linear cascade model, with linear flow within channels and temporary storage of water along floodplains during high flow periods. In the main stem Amazon the flooding can persist for more than 6 months each year [Sioli, 1984; Sippel et al., 1994]. The WBM/WTM was calibrated to match discharge hydrographs given by Richey et al. [1989] and obtained through the Departamento Nacional de Aguas e Energia Elétrica (DNAEE), Brazilia (Figures 2 and 5). Since there are few high-resolution time series that have been published, the modeled flows represent a sensible interpolation of the available discharge fields which are distributed hundreds of kilometers apart and subject to numerous sharp gradients brought about by tributary inflows. Use of these simulated flows allows us to characterize the discharge regime along much of the main stem river that would not otherwise be possible.

Annual water budgets were calculated using the calibrated model for five consecutive water years starting in September 1979. These budgets, determined for the drainage basin above
Óbidos (Table 2), showed that interannual variations were greatest in precipitation (2200-2450 mm/yr) and runoff (953$1211 \mathrm{~mm} / \mathrm{yr}$ ), while evapotranspiration remained more or less constant (1180-1263 mm/yr) over this 5-year period. There was little overall storage of water within the basin from year to year, comprising at most approximately $5 \%$ of the precipitation delivery; storage in the soil moisture component was even smaller ( $<1 \%$ of precipitation). For the period considered, mean values for precipitation, evapotranspiration, and runoff were 2302,1221 , and $1086 \mathrm{~mm} / \mathrm{yr}$, respectively. The calibrated model therefore produced a runoff ratio of $47 \%$, in excellent agreement with that earlier studies [Baumgartner and Reichel, 1975; Korzoun et al., 1977; Salati, 1985; Vörösmarty et al., 1989]. Despite good correspondence to earlier work, this budget should also be viewed in the context of recent studies suggesting the potential importance of water extraction by deeply rooted vegetation [Nepstad et al., 1994], which was not modeled explicitly here.

\section{Passive Microwave Radiometer Data}

Data representing the SMMR 37-GHz horizontally and vertically polarized temperature differences (degrees Kelvin) collected aboard the Nimbus 7 satellite were extracted from a global archive maintained by NASA's Pilot Land Data System (PLDS) Archive (Greenbelt, Maryland) and described by Choudhury et al. [1992] and Choudhury and Meeson [1992]. The archive maintains monthly composites of horizontally and vertically polarized temperature differences spanning $85.0^{\circ} \mathrm{N}$ to $85.0^{\circ} \mathrm{S}$ and $180^{\circ} \mathrm{W}$ to $180^{\circ} \mathrm{E}$. The Nimbus 7 maintains a circular Sun-synchronous orbit with an ascending equator crossing time of local noon and midnight solar time. It operates at a nominal altitude of $955 \mathrm{~km}$, an inclination of $99.28^{\circ}$, and a nodal period of approximately $104 \mathrm{~min}$. The orbital swath is $780 \mathrm{~km}$ in width, with successive orbital swaths $26^{\circ}$ apart at the equator. SMMR operated every second day giving rise to a global mapping every 6 days in the equatorial region. To minimize interference by atmospheric water vapor and dense cloud cover, the PLDS archived the second lowest daytime value for the horizontally and vertically polarized temperature difference associated with a particular month. We used as raw data the reported monthly values (HVPTD') from April 1979 through March 1985 at a resolution of $0.25^{\circ} \times 0.25^{\circ}$ (latitude by longitude) to construct the time series used in this study.

Three corrections were made to the original PLDS data set. To account for the sensor geolocation error of the beam center (on the order of $12 \mathrm{~km}$ [Choudhury et al., 1992]), the original data were first resampled to $0.5^{\circ} \times 0.5^{\circ}$ resolution using a simple spatial integration procedure that gave proportional weighting to each $0.25^{\circ}$ signal based on its areal extent within the larger $0.5^{\circ}$ cell. Next, each monthly HVPTD' value at $0.5^{\circ}$ resolution was averaged with the corresponding value from each of its five adjacent upstream cells, an integration we found optimal as discussed below. This minimized the effect of local variations in river morphology. Finally, since the original monthly HVPTD' time series was based upon a single observation taken during the named month (the second lowest of all available daytime values), a temporal sampling error was embedded within the data set. To compensate for this, a threepoint weighted moving average was applied to the resampled and upstream-integrated data:

$$
\begin{aligned}
\text { HVPTD }_{t}= & 0.25 \text { HVPTD }_{t-1}^{\prime}+0.50 \text { HVPTD }_{t}^{\prime} \\
& +0.25 \text { HVPTD }_{t+1}^{\prime}
\end{aligned}
$$


where HVPTD represents a particular month's corrected 37$\mathrm{GHz}$ polarized temperature difference and $t$ is month. The time series so constructed spanned May 1979 through February 1985.

Figure 3 shows an example of the sequential improvement in the monthly time series signal afforded by these operations for the mainstem near Óbidos. The top panel shows the resampled $0.5^{\circ} \times 0.5^{\circ}$ time series. The next sequence results from the upstream integration. The specific upriver pathways were generated from the network topology shown in Figure 1. At this point the time series begins to show a periodicity as might be expected from the presence of stage-dependent floodplain inundation, but a high degree of variability is still apparent. The time series for HVPTD developed from the three-point moving average procedure shows substantially less variability, and it is this final data set for each main stem pixel that is used in our time series analysis.

Over the defined domain, simple statistical relationships were used to link the enhanced HVPTD and the WTMderived flows. We generated a linear regression model using the least squares method for each $0.5^{\circ}$ cell distributed along the main stem (Figure 4). The calibration period started in May 1979 and ended in February 1983. A validation period was designated from March 1983 through February 1985. Some main stem sites showed a small difference in regression lines developed for rising and falling stages, indicative of a backwater effect [Meade et al., 1991]. However, owing to the relatively large uncertainties associated with both the spatial and temporal attributes of the HVPTD data set, we elected to document only the predominant relationship linking HVPTD and discharge. This was achieved using a single, linear regression at each grid location.

Model performance was evaluated using the $d$ statistic (Willmott's [1982] index of agreement). The index of agreement $(d)$ is a standardized measure of average error rather than a measure of correlation (such as Pearson's product-moment coefficient $(r)$ ). The $d$ statistic is proportional to average accuracy, and therefore it is a better indicator of model performance than is correlation [Willmott, 1982; Willmott et al., 1985c]. If we first define the mean absolute error (MAE) as

$$
\mathrm{MAE}=N^{-1} \sum_{\imath=1}^{N}\left|p_{\imath}-o_{\imath}\right|
$$

where $o$ is the observed (calibrated WTM-derived discharge) and $p$ is the HVPTD-predicted discharge, then $d$ can be expressed as

$$
d=1-[N \times \mathrm{MAE}] /\left[\sum_{i=1}^{N}\left(\left|p_{t}-\bar{o}\right|+\left|o_{t}-\bar{o}\right|\right)\right]
$$

$$
0 \leq d \leq 1.0
$$

When $d=1.0, p$ and $o$ are in perfect agreement [Willmott et al., 1985c].

\section{Results and Discussion}

On the basis of average monthly values, WTM-derived discharge and HVPTD along the main stem Amazon, from western Amazonia to the river's mouth, show parallel trends (Figure 5). A progressive increase in WTM-derived discharge and

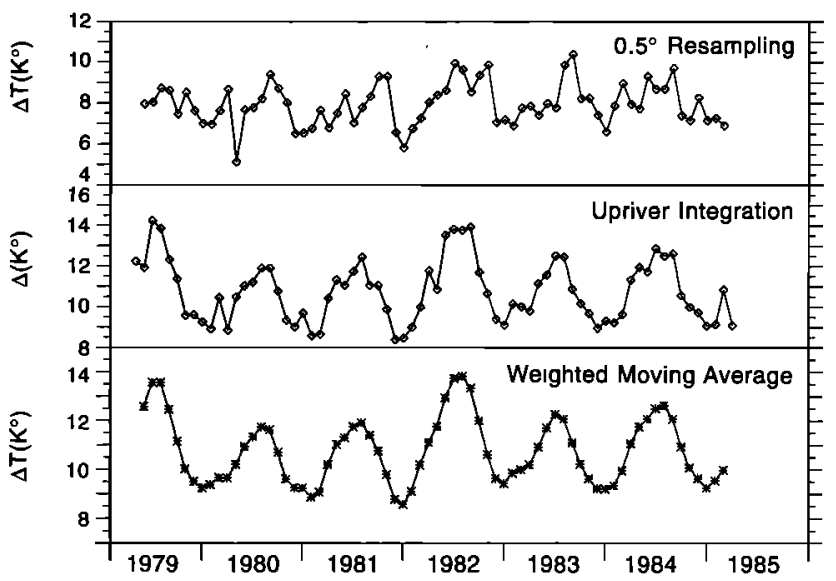

Figure 3. Example of sequential improvement in $0.25^{\circ} \times$ $0.25^{\circ}$ resolution $37-\mathrm{GHz}$ polarization temperature difference time series. The procedure used included a weighted resampling at $0.5^{\circ}$, spatial integration using data from five additional upstream cells, and application of a weighted moving average scheme as given in (2). Site shown is at Obidos $\left(56.0^{\circ} \mathrm{W}, 2.0^{\circ} \mathrm{S}\right)$.

its amplitude is apparent progressing downriver. The flow trajectory is punctuated by tributary inflows which increase, in stepwise fashion, both the downstream discharge and discharge amplitude. The HVPTD also shows a systematic increase in magnitude and amplitude from western Amazonia to a position roughly aligned with downstream cell number 40 (i.e., Óbidos), but the signal shows less of the tributary effect. The HVPTD transect also shows smaller departures from the mean during low flows, in accordance with the radiative mixing model which would predict less sensitivity when river water is confined to channels alone. Beyond cell 40 the HVPTD signal is much less regular, and the span of river influenced by tidal effects [Sioli, 1984] correlates well with this phenomenon. Sioli [1984] describes a twice-daily flooding of the alluvial islands and floodplains of the lower Amazon and this suggests that the increased variability could be related to interference between the periodicity of tides and satellite sampling frequency. Other potential causes are intensified land use in the islands near the mouth of the system, invoking an apparent shift in the mixing model end points (J. Melack, personal communication, 1995), sea breeze-induced aerosol and humidity effects, and/or differences in water surface roughness. The increase in HVPTD past cell number $\mathbf{5 0}$ is likely due to the increasing predominance of open water pixels near the mouth of the river. Because of these factors, we chose to limit the downstream domain of this analysis to the Óbidos site.

Time series of HVPTD-derived discharge were generated for both the calibration and validation periods, examples of which are given in Figure 6. The HVPTD-generated flows which correspond most closely to the WTM results are found at the more downriver, nontidal sites (Figure 6, Óbidos, Negro). At these locations there is excellent agreement in the overall magnitude of the two time series as well as in the timing of peak flows. Low flows tend to be overestimated by the HVPTD relative to WTM, in keeping with results obtained for the average monthly values depicted in Figure 5 . There is a sequential improvement in the overall performance passing from upstream to downstream sites (Table 3). Although the MAE increases in the downstream direction, it does so in tandem with even larger increases in discharge, so that in 

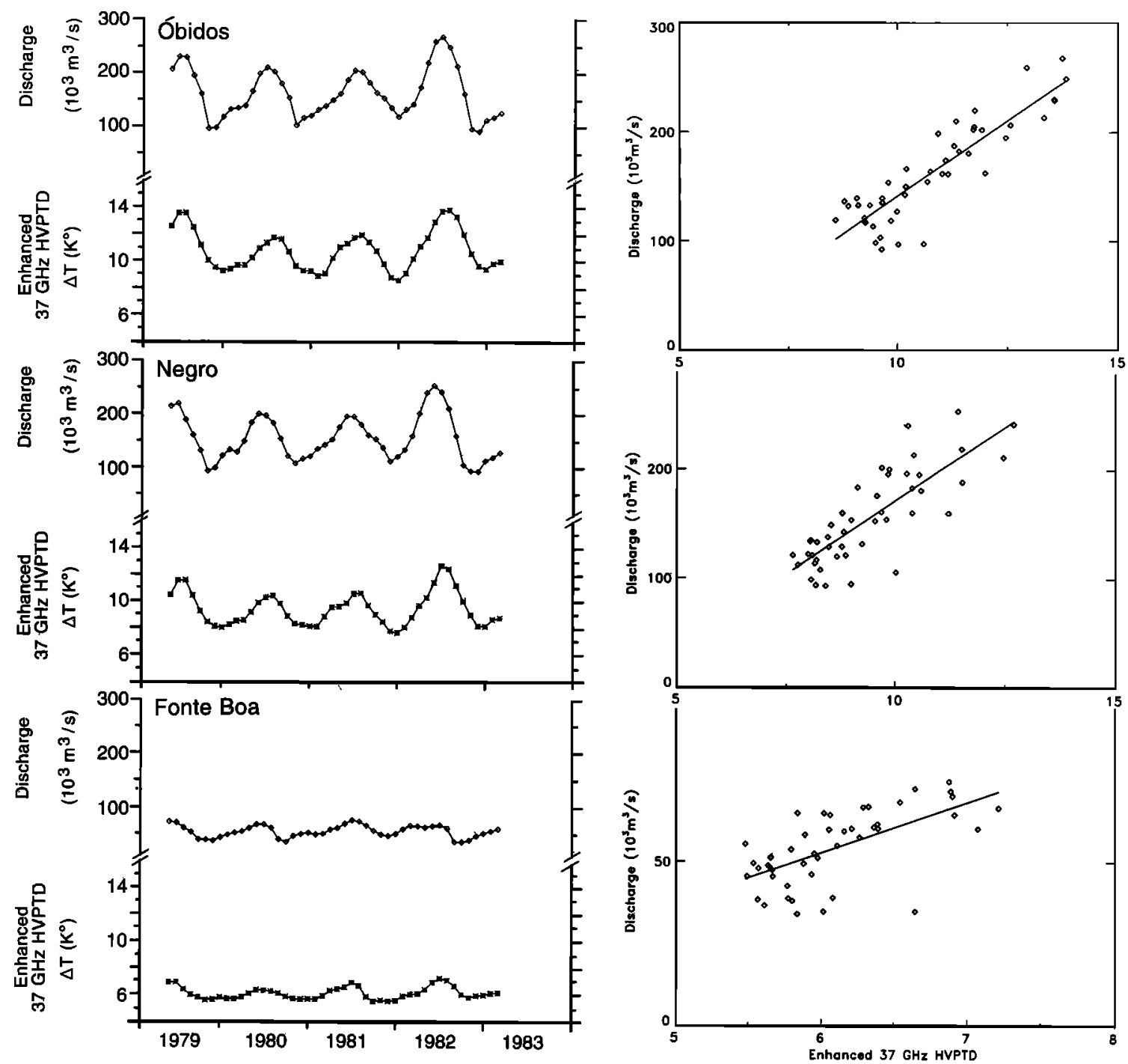

Figure 4. Typical time series plots showing calibrated discharges from the water transport model (WTM) with $37-\mathrm{GHz}$ horizontally and vertically polarized temperature differences over the calibration period from May 1979 through February 1983, Regression models linking the two data sets at each site are also shown. Mainstem sites shown are at (a) Óbidos $\left(56.0^{\circ} \mathrm{W}, 2.0^{\circ} \mathrm{S}\right)$, (b) confluence with the Rio Negro $\left(59.5^{\circ} \mathrm{W}, 3.5^{\circ} \mathrm{S}\right)$, and (c) Fonte Boa $\left(66.0^{\circ} \mathrm{W}, 2.5^{\circ} \mathrm{S}\right)$.

relative terms model performance improves in the downstream direction. Examination of the regressions indicate that the majority are statistically significant $(\alpha<0.005)$. Residual plots demonstrate no systematic biases. Although the HVPTD model for the most upriver cells does appear capable of estimating long-term average discharge, it is able to predict neither seasonal variations in flow nor year-to-year differences in river status (e.g., Figure 6, Fonte Boa). We examined whether the regression relationships could be improved by integrating the HVPTD signal over a different number of upstream grid cells. The relationships are weakened by utilizing fewer than the five contributing cells upon which we based our analysis. The $d$ statistic, however, is not enhanced appreciably by incorporating additional upriver cells. It therefore appears that the usefulness of the SMMR HVPTD to infer flows in the Amazon is confined to a reach of the mainstem between $65.0^{\circ} \mathrm{W}$ and $56.0^{\circ} \mathrm{W}$.

Flows derived from both the WTM and HVPTD provide a useful synoptic view of how Amazon River discharge varies over space and time (Figure 7). Both models show the progressive downriver increase in discharge, including the influence of tributary inflows, and the magnitudes depicted by each model are quite similar. The WTM clearly shows interannual variations in discharge, the most dramatic of which are associated with the 1982-1983 ENSO event. The HVPTD does surprisingly well throughout much of the spatial domain in capturing the same ENSO excursion and subsequent discharge dynamics during the validation period. The most upstream sites show less seasonal variability with HVPTD than with WTM-derived fields.

For the Amazon this analysis indicates that the HVPTD method of predicting discharges works best in floodplaindominated reaches with a mean annual discharge of approximately $70,000 \mathrm{~m}^{3} / \mathrm{s}$ and showing an annual excursion of 50,000 $\mathrm{m}^{3} / \mathrm{s}$. Although there is no other river in the world that experiences such high flows, this result does not necessarily disqualify the method's application elsewhere, since river-specific stage and lateral inundation relationships are the more critical 
determinants of HVPTD response. Giddings and Choudhury [1989] in fact document the HVP'TD response of several wetland and river systems that are correlated to rising and falling stage. The model we have presented should be transferable to other systems but with site-specific parameters reflecting differences in the hydrography and nature of the surrounding landscape.

There are, however, general limits to the use of satellitederived HVPTD to infer such river dynamics. The $37-\mathrm{GHz}$ signal is sensitive to scattering by vegetation so that rivers covered by dense canopy will fail to elicit a clear signal. Because the footprint size is approximately $25 \mathrm{~km}$ at nadir and the Nimbus 7 sensor has pointing inaccuracies on the order of 12 $\mathrm{km}$ [Choudhury et al., 1992], only large, floodplain-dominated rivers and wetlands show up clearly on HVPTD images [see Giddings and Choudhury, 1989]. These rivers may also represent the only pixels capable of clearly overriding the atmospheric contamination effects described by Kerr and Njoku [1991] and Choudhury et al. [1992]. Figure 8 contrasts river flow and NIMBUS 7 HVPTD in two $0.5^{\circ}$ grids located upstream of the mainstem Amazon (see Figures 1a and 1c). It is apparent that these smaller tributaries show a distorted HVPTD trajectory relative to the observed discharge and one close to the $4^{\circ} \mathrm{K}$ value for dense forest canopy discussed earlier. Clearly, more work needs to be done by applying atmospheric corrections, and the analysis of smaller rivers awaits the application of higher resolution sensors.

This study has demonstrated the use of a single passive microwave sensor to remotely monitor flow dynamics in a large

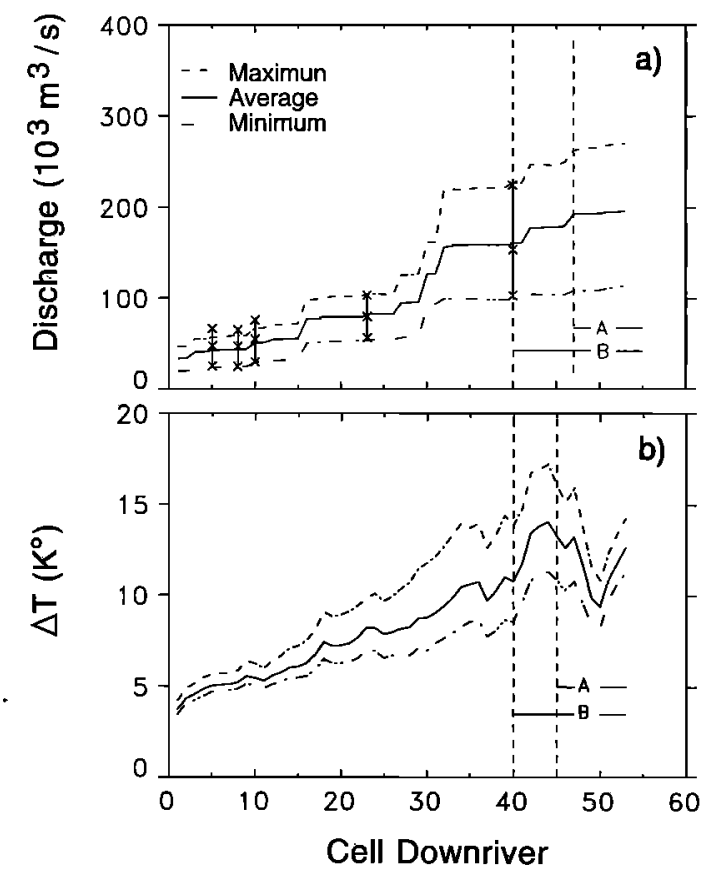

Figure 5. Transects of (a) discharge and (b) HVPTD along the main stem Amazon River. Observed annual mean, mean maximum, and mean minimum during the study period for five main stem stations taken from Richey et al. [1989] and the Brazilian Departamento Nacional de Aguas e Energia Elétrica (DNAEE). Letters "A" and "B" depict the mapping onto our grid system of, respectively, the estuary per se and the broader zone of tidal influence as given by Sioli [1984]. The 40th position is coincident with Óbidos $\left(56.0^{\circ} \mathrm{W}, 2.0^{\circ} \mathrm{S}\right)$.

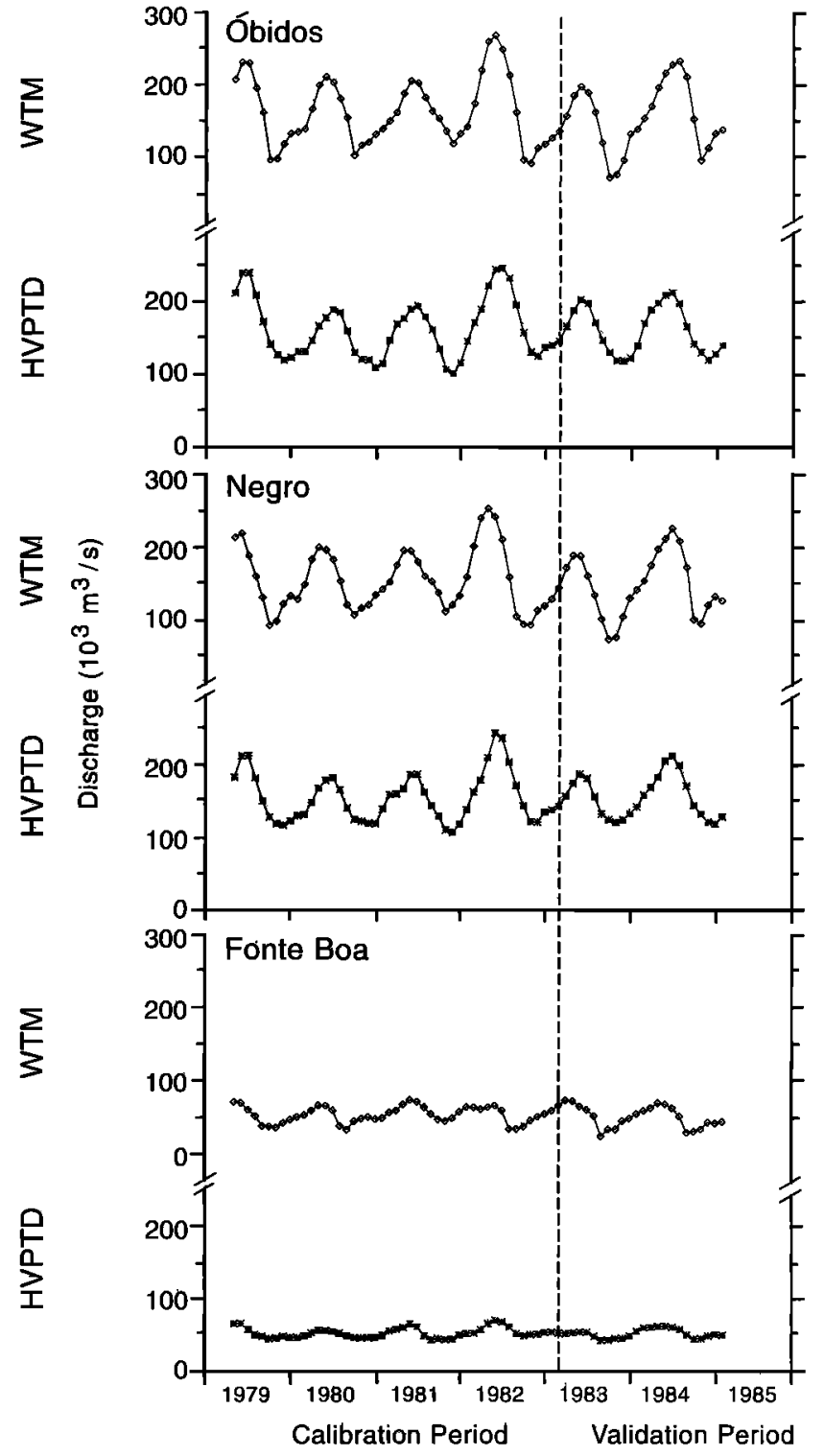

Figure 6. Time series plots showing discharges from the WTM and those derived from the HVPTD statistical model over both the calibration and validation periods. Sites shown are at (a) Óbidos $\left(56.0^{\circ} \mathrm{W}, 2.0^{\circ} \mathrm{S}\right)$, (b) confluence with the Rio Negro $\left(59.5^{\circ} \mathrm{W}, 3.5^{\circ} \mathrm{S}\right)$, and (c) Fonte Boa $\left(66.0^{\circ} \mathrm{W}, 2.5^{\circ} \mathrm{S}\right)$.

tropical river. It prepares a framework for monitoring other large rivers and for exploring the use of contemporary and future passive microwave data sets in a more direct coupling to hydrodynamic models. In particular, information obtained from the Defense Meteorological Satellite Programme's Special Sensor Microwave/Imager (SSM/I) (operational from 1987 to the present) and planned EOS-era microwaves (e.g., multifrequency imaging microwave radiometer (MIMR)) is building toward a capacity to monitor, in real time, the hydrography of large regions of the globe. The methods employed here are easily adaptable to future such studies. However, to fully account for the water status of large wetlands and naturally flowing rivers, an accurate mass balance must be determined not only by quantifying discharge but also by detecting changes in storage on floodplains and other riparian zones. The synergistic use of passive microwave, radar and radar altimetry, 
Table 3. Regression Parameters and Statistics Linking WTM-Derived Flows and HVPTD on Each Main Stem Amazon Grid Cell Used in This Analysis

\begin{tabular}{|c|c|c|c|c|c|c|c|c|c|}
\hline Cell & $\begin{array}{l}\text { Longitude, } \\
\text { deg. W }\end{array}$ & $\begin{array}{l}\text { Latitude, } \\
\text { deg. S }\end{array}$ & $b_{0}$ & $b_{1}$ & $\begin{array}{c}\text { Mean WTM } \\
\text { Discharge, } \\
10^{3} \mathrm{~m}^{3} / \mathrm{s}\end{array}$ & $\begin{array}{c}\text { Mean HVPTD } \\
\text { Discharge, } \\
10^{3} \mathrm{~m}^{3} / \mathrm{s}\end{array}$ & RMSE & MAE & $d$ Statistic \\
\hline 40 & 56.0 & 2.0 & -130.58 & 25.74 & 160.63 & 161.79 & 20.10 & 15.17 & 0.78 \\
\hline 39 & 56.5 & 2.5 & -113.37 & 26.19 & 157.97 & 159.41 & 20.00 & 14.41 & 0.78 \\
\hline 38 & 57.0 & 3.0 & -90.70 & 23.55 & 157.67 & 157.29 & 20.87 & 14.89 & 0.77 \\
\hline 37 & 57.5 & 2.5 & -75.18 & 21.60 & 157.37 & 155.86 & 20.82 & 15.02 & 0.77 \\
\hline 36 & 58.0 & 3.0 & -74.04 & 22.18 & 157.24 & 156.06 & 21.20 & 15.64 & 0.76 \\
\hline 35 & 58.5 & 3.0 & -76.86 & 22.70 & 156.72 & 156.16 & 22.37 & 17.05 & 0.73 \\
\hline 34 & 58.5 & 3.5 & -62.37 & 21.50 & 155.86 & 156.54 & 21.24 & 16.15 & 0.74 \\
\hline 33 & 59.0 & 3.5 & -64.84 & 23.55 & 155.55 & 156.26 & 21.85 & 16.88 & 0.73 \\
\hline 32 & 59.5 & 3.5 & -73.32 & 26.72 & 153.99 & 155.45 & 21.49 & 16.55 & 0.73 \\
\hline 31 & 60.0 & 3.5 & -15.26 & 17.51 & 126.89 & 128.12 & 13.75 & 10.61 & 0.73 \\
\hline 30 & 60.5 & 3.5 & -16.26 & 17.65 & 126.49 & 127.65 & 14.60 & 11.26 & 0.72 \\
\hline 29 & 61.0 & 3.5 & -6.30 & 13.11 & 95.12 & 95.87 & 15.45 & 11.45 & 0.60 \\
\hline 28 & 61.0 & 4.0 & -23.81 & 16.48 & 94.34 & 95.29 & 15.46 & 11.33 & 0.59 \\
\hline 27 & 61.5 & 4.0 & -27.28 & 14.78 & 94.14 & 94.62 & 15.95 & 11.60 & 0.57 \\
\hline 26 & 62.0 & 4.0 & -21.65 & 12.07 & 81.23 & 81.32 & 10.34 & 7.25 & 0.65 \\
\hline 25 & 62.5 & 4.0 & -30.09 & 13.99 & 81.26 & 81.46 & 10.36 & 7.36 & 0.65 \\
\hline 24 & 63.0 & 4.0 & -29.68 & 14.10 & 81.26 & 81.68 & 10.56 & 7.44 & 0.65 \\
\hline 23 & 63.5 & 4.5 & -36.75 & 14.70 & 80.70 & 81.11 & 10.33 & 7.26 & 0.65 \\
\hline 22 & 63.5 & 4.0 & -37.42 & 14.77 & 77.98 & 77.92 & 9.45 & 6.38 & 0.70 \\
\hline 21 & 64.0 & 4.0 & -29.10 & 14.31 & 78.01 & 77.97 & 9.18 & 6.29 & 0.70 \\
\hline 20 & 64.5 & 4.0 & -28.49 & 14.75 & 78.02 & 77.99 & 9.29 & 6.62 & 0.68 \\
\hline 19 & 64.5 & 3.5 & -26.13 & 14.50 & 77.82 & 77.84 & 9.29 & 6.76 & 0.67 \\
\hline 18 & 65.0 & 3.5 & -41.33 & 17.36 & 76.98 & 76.76 & 8.98 & 6.54 & 0.68 \\
\hline 17 & 65.5 & 3.0 & -39.51 & 17.83 & 74.99 & 74.60 & 8.54 & 6.41 & 0.68 \\
\hline 16 & 65.5 & 2.5 & -38.35 & 18.30 & 74.66 & 74.35 & 9.70 & 7.40 & 0.63 \\
\hline 15 & 66.0 & 2.5 & -36.44 & 16.46 & 53.35 & 53.35 & 8.31 & 6.31 & 0.57 \\
\hline 14 & 66.5 & 3.0 & -38.48 & 17.09 & 52.49 & 52.81 & 8.38 & 6.51 & 0.56 \\
\hline 13 & 67.0 & 3.0 & -47.25 & 18.24 & 52.30 & 52.48 & 8.46 & 6.57 & 0.55 \\
\hline 12 & 67.5 & 3.0 & -37.95 & 16.57 & 51.88 & 51.76 & 9.10 & 7.04 & 0.48 \\
\hline 11 & 68.0 & 3.0 & -41.65 & 17.20 & 48.84 & 49.11 & 9.05 & 6.86 & 0.45 \\
\hline 10 & 68.0 & 3.5 & -43.17 & 18.25 & 48.64 & 49.17 & 9.16 & 6.97 & 0.43 \\
\hline 9 & 68.5 & 3.5 & -36.36 & 15.03 & 41.90 & 42.08 & 8.76 & 6.72 & 0.39 \\
\hline 8 & 69.0 & 3.5 & -35.31 & 15.13 & 41.42 & 41.18 & 8.95 & 6.99 & 0.34 \\
\hline 7 & 69.5 & 3.5 & -27.98 & 13.35 & 40.73 & 40.59 & 9.01 & 7.08 & 0.30 \\
\hline 6 & 69.5 & 4.0 & -38.75 & 15.16 & 40.23 & 39.97 & 8.79 & 6.89 & 0.35 \\
\hline 5 & 69.5 & 4.5 & -34.00 & 14.33 & 39.72 & 39.31 & 8.83 & 6.94 & 0.34 \\
\hline 4 & 70.0 & 4.5 & -34.41 & 14.00 & 38.08 & 37.47 & 8.52 & 6.59 & 0.37 \\
\hline 3 & 70.5 & 4.5 & -30.92 & 13.46 & 38.08 & 37.54 & 8.67 & 6.76 & 0.35 \\
\hline 2 & 70.5 & 4.0 & -42.15 & 14.12 & 31.00 & 30.50 & 6.98 & 5.30 & 0.43 \\
\hline 1 & 71.0 & 4.0 & -31.13 & 11.90 & 30.74 & 30.35 & 7.30 & 5.56 & 0.38 \\
\hline
\end{tabular}

Mean flow rates are also shown for the calibration period. The most downriver sites appear at the top of the table. The values $b_{0}$ and $b_{1}$ are the intercept and slope of the linear regression with HVPTD as the independent variable. The regression yields discharge in units of $10^{3}$ cubic meters per second. Georeferencing refers to the SW corner of each $0.5^{\circ} \times 0.5^{\circ}$ (latitude by longitude) grid cell. RMSE and MAE are computed on a monthly basis.

optical sensors, and satellite telemetry for ground-based data transmission requires suitable exploration in this context.

\section{Summary and Conclusions}

This study demonstrated the concurrent use of groundbased meteorological station data, passive microwave radiometer data, and calibrated water balance and transport models to infer flow regime in a large, floodplain-dominated river. The study applied these tools in a quantitative assessment of water status in the Amazon drainage basin for each month from May 1979 through February 1985. This research showed that data from the SMMR aboard the Nimbus 7 satellite can be used to reasonably estimate discharge along the mainstem Amazon using regression relationships linking horizontally and vertically polarized temperature differences at $37 \mathrm{GHz}$ to flow regime determined by a calibrated model. The exercise required preprocessing of the satellite data to correct for spatial and temporal sampling errors. The domain under which the satel- lite-derived discharges appear to be reasonable was identified, and this reach spans more than $1400 \mathrm{~km}$ of main stem river. In this domain both modeled and satellite-derived discharges showed large within-year variations. Both approaches were capable of simulating the effect of the 1982-1983 ENSO, showing sharply decreased flows associated with the event.

Although there are limits to the use of such satellite-derived discharge models, this research has clearly demonstrated their potential to remotely monitor the status of river systems in real time. Through collaborative research with the University of California (Santa Barbara) we are currently developing methods to more directly couple $37-\mathrm{GHz}$ microwave time series data from both the SMMR and its successor, the SSM/I, to our hydrology model. The strategy is to use remote sensing data in conjunction with ground-based observations to more accurately invoke within our hydrology model both the onset and cessation of floodplain inundation and to provide an indication of the extent of such flooding. 

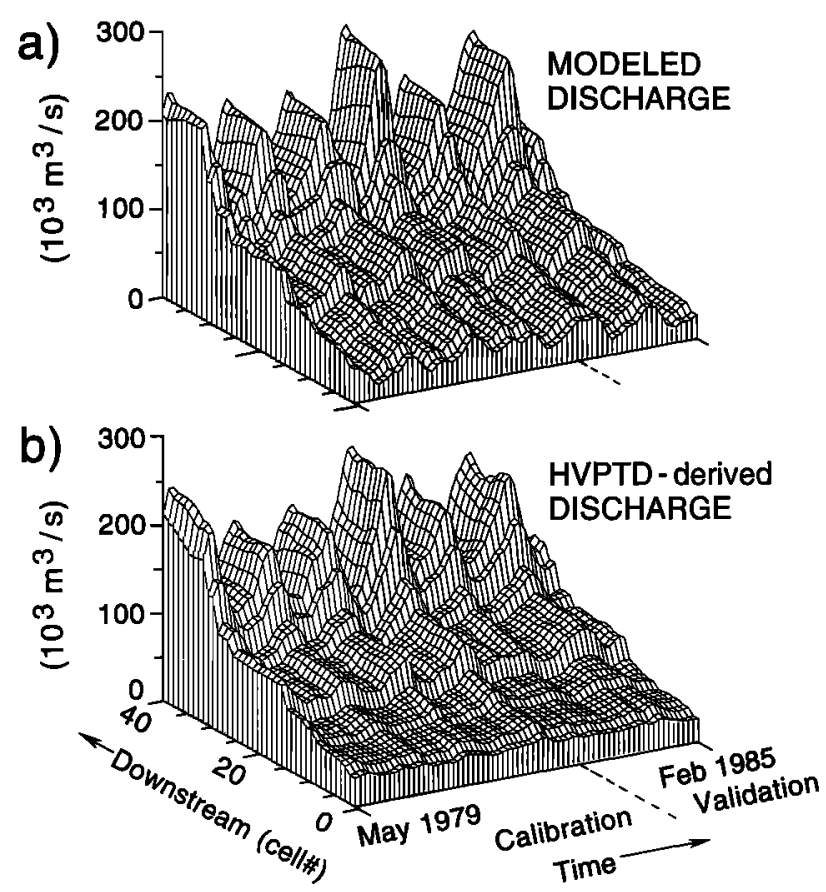

Figure 7. Time series for river discharge along the mainstem Amazon, generated by (a) the calibrated water balance/ transport model and (b) the 37-GHz HVPTD statistical model.

Progress toward a real-time monitoring capability is especially important in remote areas and where there has been a deterioration in observational networks. Developing appropriate monitoring tools will help to enhance our knowledge of the dynamics of the water cycle over broad geographic domains from both a scientific as well as a water resources management perspective. We have demonstrated the possibility of monitor-

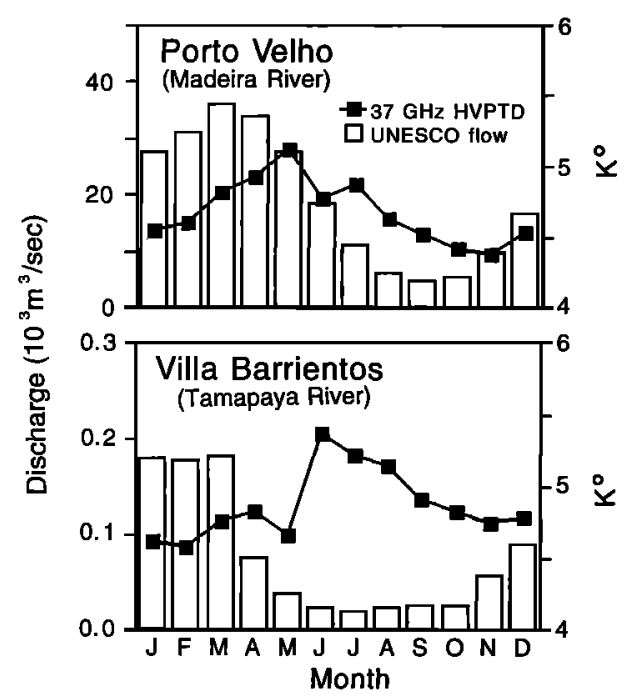

Figure 8. Illustrations of the decoupling of HVPTD and river discharge for two grid cells within the Amazon basin (Porto Velho, 64.0 $0^{\circ} \mathrm{W}, 9.0^{\circ} \mathrm{S}$; Villa Barrientos, $\left.67.5^{\circ} \mathrm{W}, 16.5^{\circ} \mathrm{S}\right)$. The influence of dense canopy and site-specific hydrography limit the general utility of the 37-GHz HVPTD model in this region (note HVPTD scale in relation to Figures 3 and 4). Higher resolution and multiple-sensor analysis may be required to adequately monitor such tropical river systems remotely. ing the dynamics of a large tropical river with a relatively coarse passive microwave sensor. An operational capacity for smaller river systems will ultimately require higher-resolution sensors, more detailed atmospheric corrections, and techniques that exploit synergistic optical, passive and active microwave sensors.

\section{Appendix: Model Description}

\section{Water Balance Model (WBM)}

The water balance model simulates soil moisture variations, evapotranspiration, and runoff on single grid cells using biophysical data sets that include climatic drivers, vegetation, and soil properties. The state variables are determined by interactions among time-varying precipitation, potential evapotranspiration, and soil water content. The original model is described in detail by Vörösmarty et al. [1989] and Vörösmarty and Moore [1991]. The governing equations can be summarized as follows:

$$
\begin{gathered}
\frac{d W_{s}}{d t}=-g\left(W_{s}\right)\left(E_{p}-P_{r}\right) \quad P_{r} \leq E_{p} \\
\frac{d W_{s}}{d t}=P_{r}-E_{p} \quad E_{p}<P_{r} \leq D_{w s} \\
\frac{d W_{s}}{d t}=D_{w s}-E_{p} \quad D_{w s}<P_{r} \\
E_{e}=P_{r}-\frac{d W_{s}}{d t} \quad P_{r} \leq E_{p} \\
E_{c}=E_{p} \quad E_{p}<P_{r} \\
X_{r}=0 \quad P_{r} \leq D_{w s} \\
X_{r}=P_{r}-D_{w s} \quad D_{w s}<P_{r}
\end{gathered}
$$

where $W_{s}$ is soil moisture (in millimeters), $g\left(W_{s}\right)$ is a unitless soil drying function (see below), $E_{p}$ is potential evapotranspiration (in millimeters per day), $\boldsymbol{P}_{r}$ is precipitation as rainfall (in millimeters per day), $D_{w s}$ is soil moisture deficit (in millimeters per day) equal to the amount of water required within 1 day to fill soil to its water-holding capacity and simultaneously satisfy $E_{p}, E_{e}$ is estimated evapotranspiration (in millimeters per day), and $X_{r}$ is the rainfall excess (in millimeters per day) that is available for runoff and recharge of runoff detention pools. The unitless drying function we employ in this study is

$$
g\left(W_{s}\right)=\frac{1-\exp \left[-\alpha\left(W_{s} / C\right)\right]}{1-\exp (-\alpha)}
$$

where $\alpha$ is an empirical constant and $C$ is the soil and vegetation-dependent available water capacity (Table 1). We set $\alpha$ equal to 5.0, so that the drying curve would resemble that of Pierce [1958] when $\left(g\left(W_{s}\right)=E_{e} / E_{p}\right)$ is plotted as a function of $\left(W_{s} / C\right)$ during periods of no precipitation.

Subsequent modifications to the original WBM were instituted to reduce temporal aggregation bias arising from the use of climatic drivers available at monthly, instead of daily, time steps. These modifications are based on a scaling procedure developed by Rastetter et al. [1992]. The resulting modification of (A1a)-(A1c) is 


$$
\begin{aligned}
\frac{d W_{s}}{d t}= & p P_{r}\left\{g\left(W_{s}\right)+\left[1-g\left(W_{s}\right)\right] \exp \left[-\left(E_{p} / P_{r}\right)\right]\right. \\
& \left.-\exp \left[-\left(D_{s w} / P_{r}\right)\right]\right\}-E_{p} g\left(W_{s}\right)
\end{aligned}
$$

where $p$ is the probability that a day is rainy. The value of $p$ is obtained from $p=1-\exp \left(-u P_{r m}\right)$ where $P_{r m}$ is the monthly precipitation (in millimeters per month) and where $u$, set at 0.005 , provided a best fit to observed data over a broad geographic range. These data encompassed several ecozones including tropical and temperate rainforest, temperate deciduous and evergreen forest, grasslands, and desert. The derivation of (A5) assumes that there is an exponential distribution of rainfall amounts during those days that are rainy within a month. The daily value of $P_{r}$ is a function of $P_{r m}, p$, and $n_{d}$, the number of days in a month (i.e., $P_{r}=P_{r m} / n_{d} p$ ). We have assumed that the within-month variability in potential evapotranspiration is much less than for rainfall and can be approximated by $E_{p}=E_{p m} / n_{d}$, where $E_{p m}$ is computed potential evapotranspiration (in millimeters per month).

When precipitation exceeds the soil moisture deficit (A3b) the excess is used to augment a runoff detention pool and to generate runoff:

$$
\begin{gathered}
\frac{d D_{r}}{d t}=(1-\gamma) X_{r}-\beta D_{r} \\
R_{r}=\gamma X_{r}+\beta D_{r}
\end{gathered}
$$

where $D_{r}$ is the runoff detention pool (in millimeters) and $R_{r}$ is rainfall-derived runoff (in millimeters per day) emerging from the grid cell; $\beta$ and $\gamma$ are empirical constants, set to $0.0164 \mathrm{day}^{-1}$ and 0.5 , respectively, based on our earlier modeling studies of the Amazon.

The time-varying changes in $W_{s}$ and $D_{r}$ are solved using a fifth-sixth-order Runge-Kutta integration technique (International Mathematical and Statistical Libraries, Houston, Texas) and expressed as a daily average for the duration of each month. The expected monthly changes in these pools are thus calculated as the average daily change multiplied by $n_{d}$, the number of days in each month. Likewise, the associated water fluxes computed by WBM are initially expressed as a daily average for the duration of each month. These also are multiplied by $n_{d}$ to obtain corresponding monthly values. Runoff determined in this way is passed to the WTM for subsequent routing downstream.

\section{Water Transport Model (WTM)}

The water transport model [Vörösmarty et al., 1989] is a quasi-linear reservoir model that computes discharge through each grid cell of the simulated river basin based on runoff inputs from WBM, a river networking system (Figure 1b), channel transfer rates, and the timing and extent of floodplain inundation. For a single grid cell the flow and continuity equations are

$$
\begin{gathered}
\frac{d S_{\mathrm{c}}}{d t}=\left(\sum_{1}^{n} Q_{u}\right)-Q_{d}+Q_{g}+Q_{f} \\
\frac{d S_{f}}{d t}=-Q_{f} \\
Q_{d}=K S_{c}
\end{gathered}
$$

$$
\begin{gathered}
Q_{g}=A\left(X_{\mathrm{r}}\right) / 1000 \\
Q_{f}=-r_{f}\left[\left(\sum_{1}^{n} Q_{u}\right)-Q_{d}+Q_{g}\right] \\
Q_{d} \geq c_{f} Q_{d m a} \\
Q_{f}=0 \quad Q_{d}<c_{f} Q_{d m a}
\end{gathered}
$$

where $S_{c}$ is the channel storage (in cubic meters), $S_{f}$ is floodplain storage (in cubic meters), $K$ is the downstream transfer coefficient (per month), $A$ is the grid cell plan area (in square meters), $n$ is the number of upstream donor cells, $Q_{u}$ is an upriver inflow, $Q_{d}$ is the discharge exported downstream, $Q_{g}$ is the runoff generated locally within the grid cell considered, $Q_{f}$ is exchange between channel and floodplain (a plus denotes floodplain-to-channel exchange), and $Q_{d m a}$ is the long-term mean annual downstream discharge. All $Q$ values are in cubic meters per month. The coefficient $r_{f}$ determines the fraction ( 0.0 to 1.0$)$ of potential volume change that is assigned to floodplain storage, and $c_{f}$ is the flood initiation parameter, giving the proportion ( 0.0 to 1.0$)$ of long-term mean annual flow required to invoke floodplain exchanges. The established network topology together with (A7a) and (A7b) creates a system of differential equations that is solved for $S_{c}$ and $S_{f}$ using the same numerical integrator as that in the WBM.

Acknowledgments. We wish to acknowledge the efforts of John Canfield for his help with data assembly and checking and of Sherry Palmer and Tom Hibschman for their very careful preparation of the graphics. We thank Eurides Oliveira of the Brazilian DNAEE for Amazon River gauging data. This research was supported in part by the National Aeronautics and Space Administration (grants NAGW1884, 1888, and 2669) and the U. S. Environmental Protection Agency (cooperative agreement CR816278). We also recognize the efforts of three anonymous reviewers who made numerous constructive suggestions for improving this manuscript.

\section{References}

Arkin, P., and J. Janowiak, Analyses of the global distribution of precipitation, Dyn. Atmos. Oceans, 16, 5-16, 1991.

Arnell, N., and N. Reynard, Estimating the impacts of climatic change on river flows: Some examples from Britain, in Conference on Climate and Water, Helsinki, Sept. 11-15, Acad. of Finland Publ., Helsinki, 1989.

Baumgartner, F., and E. Reichel, The World Water Balance: Mean Annual Global, Continental, and Maritime Precipitation, Evaporation and Runoff, Ordenbourg, Munich, 1975.

Birkett, C. M., Radar altimetry: A new concept in monitoring lake level changes, Eos Trans. $A G U, 75,274-276,1994$.

Chahine, M. T., The hydrological cycle and its influence on climate, Nature, 359, 373-380, 1992.

Choudhury, B. J., Monitoring global land surface using Nimbus-7 37 $\mathrm{GHz}$ data theory and examples, Int. J. Remote Sens., 10, 1579-1605, 1989.

Choudhury, B. J., and B. Meeson, Microwave Vegetation Index: Data Set Documentation, Product Description, and User's Guide, Pilot Land Data System User Publication, NASA, 1992.

Choudhury, B. J., E. R. Major, E. A. Smith, and F. Becker, Atmospheric effects on SMMR and SSM/I $37 \mathrm{GHz}$ polarization difference over the Sahel, Int. J. Remote Sens., 13, 3443-3463, 1992.

Committee on Global Change, Toward an Understanding of Global Change: Initial Priorities for the U.S. Contributions to the International Geosphere-Biosphere Program, Nat. Acad. Press, Washington, D. C., 1988.

Defense Mapping Agency Aerospace Center (DMAAC), Operational navigation charts M-25, N-25, N-27, and P-28, St. Louis, Mo., 1980. 
Defense Mapping Agency Aerospace Center (DMAAC), Operational navigation chart P-26, St. Louis, Mo., 1981.

Defense Mapping Agency Aerospace Center (DMAAC), Operational navigation chart L-27, St. Louis, Mo., 1982.

Defense Mapping Agency Aerospace Center (DMAAC), Operational navigation charts N-26 and P-27, St. Louis, Mo., 1983.

Defense Mapping Agency Aerospace Center (DMAAC), Operational navigation charts L-28, M-26 and M-27, St. Louis, Mo., 1984.

Defense Mapping Agency Aerospace Center (DMAAC), Operational navigation chart L-26, St. Louis, Mo., 1986.

Dickinson, R. E., and A. Henderson-Sellers, Modeling tropical deforestation: A study of GCM land-surface parameterizations, $Q$. $J . R$. Meteorol. Soc., 114, 439-462, 1988.

Dümenil, L. and E. Todini, A rainfall-runoff scheme for use in the Hamburg climate model, in Advances in Theoretical Hydrology, $A$ Tribute to James Dooge, Eur. Geophys. Soc. Ser. of Hydrol. Sci., vol. 1, edited by J. P. O'Kane, pp. 129-157, Elsevier, New York, 1992.

Food and Agriculture Organization-United Nations Educational, Scientific, and Cultural Organization (FAO-UNESCO), Soil map of the world, 1:5,000,000, vol. IV, South America, U. N. Educ., Sci., and Cult. Org., Paris, 1971.

Giddings, L., and B. J. Choudhury, Observation of hydrological features with Nimbus-7 $37 \mathrm{GHz}$ data, applied to South America, Int. J. Remote Sens., 10, 1673-1686, 1989.

Global Precipitation Climatology Centre (GPCC), Monthly precipitation estimates based on gauge measurements on the continents for the year 1987 (preliminary results) and future requirements, Rep. $D W D / K 7 / W Z N-1992 / 08-1$, World Clim. Res. Prog. and Deutscher Wetterdienst, Offenbach, Germany, 1992.

Global Runoff Data Centre (GRDC), Global Runoff Data Centre (GRDC), Fed. Inst. of Hydrol., Koblenz, Germany, 1993.

Henderson-Sellers, A., and V. B. Brown (Eds.), PILPS, Global Energy and Water Cycle Experiment, Project for intercomparison of landsurface parameterization schemes, PILPS Workshop Report and First Science Plan, Columbia, Md., June, 1992.

Imhoff, M. L., C. Vermillion, M. H. Story, A. M. Choudhury, A. Gafoor, and F. Polycn, Monsoon flood boundary delineation and damage assessment using space borne imaging radar and Landsat data, Photogramm. Eng. Remote Sens., 53, 405-413, 1987.

Kalma, J. D., and I. R. Calder, Land Surface Processes in Large-scale Hydrology, WMO Oper. Hydrol. Rep. 40, World Meteorol. Org., Geneva, 1994.

Kerr, Y. H., and E. G. Njoku, On the use of passive microwaves at 37 GHz, paper presented at 5th International Colloquium on Physical Measurements and Signatures in Remote Sensing, Toulouse, France, Jan. 14-18, 1991.

Koblinsky, C. J., R. T. Clarke, A. C. Brenner, and H. Frey, The measurement of river levels with satellite altimetry, Wat. Resour. Res., 29, 1839-1848, 1993 .

Korzoun, V. I., A. A. Sokolov, M. I. Budyko, K. P. Voskresensky, G. P. Kalinin, A. A. Konoplyantsev, E. S. Korotkevich, and M. I. Lvovich, Atlas of World Water Balance, U. N. Educ., Sci., and Cult. Org., Paris, 1977.

Lean, J., and D. A. Warrilow, Simulation of the regional climatic impact of Amazon deforestation, Nature, 342, 411-413, 1989.

Legates, D. R., and C. J. Willmott, Mean seasonal and spatial variability in global surface air temperature, Theor. Appl. Clim., 41, 11-21, 1990a.

Legates, D. R., and C. J. Willmott, Mean seasonal and spatial variability in gauge-corrected, global precipitation, Int. J. Climatol., 10, 111-127, 1990b.

Meade, R. H., J. M. Rayol, S. C. DaConceicão, and J. R. G. Natividade, Backwater effects in the Amazon River basin of Brazil, Environ. Geol. Water Sci., 18, 105-114, 1991.

Melillo, J. M., A. D. McGuire, D. W. Kicklighter, B. Moore III, C. J. Vörösmarty, and A. L. Schloss, Global climate change and terrestrial net primary production, Nature, 363, 234-240, 1993.

Mintz, Y., and Y. V. Serafini, Global Fields of Monthly Normal Soil Moisture, as Derived From Observed Precipitation and an Estimated Potential Evapotranspiration, Lab. for Atmos. Sci., Natl. Aeronaut. and Space Admin., Goddard Space Flight Cent., Greenbelt, Md., 1984.

Mintz, Y., and Y. V. Serafini, Global Monthly Climatology of Soil Moisture and Water Balance, UNESCO Studies and Reports in Hydrology, 1989.

Mintz, Y., and G. K. Walker, Global fields of soil moisture and land surface evapotranspiration derived from observed precipitation and surface air temperature, J. Appl. Meteorol., 32, 1305-1334, 1993.

Morris, C. S., and S. K. Gill, Variation in Great Lakes water levels derived from Geosat altimetry, Wat. Resour. Res., 30, 1009-1017, 1994.

Nepstad, D., C. R. de Carvalho, E. A. Davidson, P. H. Jipp, P. A. Lefebvre, G. H. Negreiros, E. D. da Silva, T. A. Stone, S. E. Trumbore, and S. Vieira, The role of deep roots in the hydrological and carbon cycles of Amazon forests and pastures, Nature, 372, 666-669, 1994.

Pierce, L. T., Estimating seasonal and short-term fluctuations in evapotranspiration from meadow crops, Bull. Am. Meteorol. Soc., 39, 73-78, 1958.

Rastetter, E. B., A. W. King, B. J. Cosby, G. M. Hornberger, R. V. O'Neill, and J. E. Hobbie, Aggregating fine-scale ecological knowledge to modeling coarser-scale attributes of ecosystems, Ecol. Appl., 2, 55-70, 1992.

Richey, J. E., L. A. K. Mertes, T. Dunne, R. L. Victoria, B. R. Forsberg, A. Tancredi, and E. Oliveira, Sources and routing of the Amazon River flood wave, Global Biogeochem. Cycles, 3, 191-204, 1989.

Rodda, G. C., S. A. Pieyns, N. S. Sehmi, and G. Matthews, Towards a world hydrological cycle observing system, Hydrol. Sci., 38, 373-378, 1993.

Rzóska, J., On the Nature of Rivers, with Case Stories of Nile, Zaire and Amazon, 67 pp., Dr. W. Junk, Norwell, Mass., 1978.

Salati, E., The climatology and hydrology of Amazonia, in Key Environments: Amazonia, edited by G. T. Prance and T. E. Lovejoy, pp. 18-48, Pergamon, Tarrytown, N. Y., 1985.

Salati, E., and P. B. Vose, Amazon Basin: A system in equilibrium, Science, 225, 129-138, 1984.

Serafini, Y. V., and Y. C. Sud, The time scale of the soil hydrology using a simple water budget model, J. Clim., 7, 585-591, 1987.

Shepard, D., A two dimensional interpolation function for irregularly spaced data, Proceedings of the 23rd National Conference, pp. 517523, Assoc. for Comput. Mach., Princeton, N. J., 1968.

Shukla, J., C. Nobre, and P. Sellers, Amazon deforestation and climate change, Science, 247, 1322-1325, 1990.

Simpson, J. (Ed.), TRMM, A Satellite Mission to Measure Tropical Rainfall, Report of the Scientific Steering Group, Natl. Aeronaut. and Space Admin., Goddard Space Flight Cent., Greenbelt, Md., 1992. Sioli, $H$., The Amazon and its main affluents: Hydrography, morphology of the courses, and river types, in The Amazon, Limnology and Landscape Ecology of a Mighty Tropical River and Its Basin, Monogr. Biol., vol. 56, edited by H. Sioli, pp. 127-165, Kluwer Acad., Norwell, Mass., 1984.

Sippel, S. J., S. K. Hamilton, and J. M. Melack, Inundation area and morphometry of lakes on the Amazon River floodplain, Brazil, Arch. Hydrobiol., 123, 385-400, 1992.

Sippel, S. J., S. K. Hamilton, J. M. Melack, and B. J. Choudhury, Determination of inundation area in the Amazon River floodplain using the SMMR $37 \mathrm{GHz}$ polarization difference, Remote Sens. Environ., 48, 70-76, 1994.

Skole, D., and C. Tucker, Tropical deforestation and habitat fragmentation in the Amazon: Satellite data from 1978-1988, Science, 260, 1905-1910, 1993.

van der Leeden, F., F. L. Troise, and D. K. Todd, The Water Encyclopedia, 2nd ed., A. F. Lewis, New York, 1990.

Vörösmarty, C. J., Models of macro-scale hydrology for use in global change research: Tests on two tropical river systems, Ph.D. dissertation, 255 pp., Univ. of N. H., Durham, 1991.

Vörösmarty, C. J., and B. Moore III, Modeling basin-scale hydrology in support of physical climate and global biogeochemical studies: An example using the Zambezi River, Stud. Geophys., 12, 271-311, 1991.

Vörösmarty, C. J., B. Moore, A. Grace, B. J. Peterson, E. B. Rastetter, and J. Melillo, Distributed parameter models to analyze the impact of human disturbance of the surface hydrology of a large tropical drainage basin in southern Africa, in Hydrology for the Water Management of Large River Basins, IAHS Publ. 201, edited by F. H. M. van de Ven, D. Gutnecht, D. P. Loucks, and K. A. Salewicz, pp. 233-44, 1991.

Vörösmarty, C. J., B. Moore, A. L. Grace, M. P. Gildea, J. M. Melillo, B. J. Peterson, E. B. Rastetter, and P. A. Steudler, Continental scale models of water balance and fluvial transport: An application to South America, Global Biogeochem. Cycles, 3, 241-265, 1989.

Vose, R. S., R. L. Schmoyer, P. M. Steurer, T. C. Peterson, R. Heim, 
T. R. Karl, and J. K. Eisheid, The Global Historical Climatology Network: Long-Term Monthly Temperature, Precipitation, Pressure, and Station Pressure Data, CDLAC-53, NDP-041, Oak Ridge Natl. Lab., Oak Ridge, Tenn., 1992.

Watson, R. T., M. C. Zinyowera, and R. H. Moss (Eds.), Climate Change 1995: Impacts, Adaptations, and Mitigation of Climate Change: Scientific-Technical Analyses, Cambridge Univ. Press, New York, 1996.

Webb, R. W., and C. E. Rosenzweig, Specifying land surface characteristics in general circulation models: Soil profile data set and derived water-holding capacities, Global Biogeochem. Cycles, 7, $97-$ $108,1993$.

Willmott, C. J., Some comments on the evaluation of model performance, Bull. Am. Meteorol. Soc., 63, 1309-1313, 1982.

Willmott, C. J., and S. M. Robeson, Climatologically-aided interpolation (CAI) of terrestrial air temperature, Int. J. Climatol., 15, 221229, 1995.

Willmott, C. J., C. M. Rowe, and Y. Mintz, Climatology of the terrestrial seasonal water cycle, J. Clim., 5, 589-606, 1985a.

Willmott, C. J., C. M. Rowe, and W. D. Philpot, Small-scale climate maps: A sensitivity analysis of some common assumptions associated with grid point interpolation and contouring, Am. Cartogr., 12, 5-16, 1985 b.

Willmott, C. J., S. G. Ackleson, R. E. Davis, J. J. Feddema, K. M. Klink, D. R. Legates, J. O'Donnell, and C. M. Rowe, Statistics for the evaluation and comparison of models, J. Geophys. Res., 90, 8995-9005, 1985c.

Willmott, C. J., S. M. Robeson, and J. J. Feddema, Estimating conti- nental and terrestrial precipitation averages from raingauge networks, Int. J. Climatol., 14, 403-14, 1994.

World Meteorological Organization/United Nations Educational, Scientific, and Cultural Organization, (WMO/UNESCO), Report on Water Resources Assessment, Progress in the Implementation of the Mar del Plata Action Plan and a Strategy for the 1990s, UN Water Conference, Angentina, U. N. Educ., Sci., and Cult. Org., Paris, 1991.

Wood, E. F. (Ed.), Land Surface-Atmosphere Interactions for Climate Modeling: Observations, Models and Analysis, Kluwer Acad., Norwell, Mass., 1991.

World Climate Research Programme, Scientific plan for the GEWEX Continental Scale International Project (GCIP), WCRP-67 WMO/TD 461, 1992.

B. J. Choudhury, Hydrological Sciences Branch, NASA Goddard Space Flight Center, Greenbelt, MD 20771.

T. J. Dorman, Science Systems and Applications, Inc., Lanham, MD 20703.

S. M. Robeson, Department of Geography, Indiana University, Bloomington, IN 47401 .

A. L. Schloss, T. K. Stearns, and C. J. Vörösmarty, Institute for the Study of Earth, Oceans, and Space, University of New Hampshire, Durham, NH 03824.

C. J. Willmott, Center for Climatic Research, Department of Geography, University of Delaware, Newark, DE 19716.

(Received September 12, 1995; revised April 17, 1996; accepted April 29, 1996.) 